Article

\title{
Techno-Economic Assessment of Cell-Free Synthesis of Monoclonal Antibodies Using CHO Cell Extracts
}

\author{
Vaishali Thaore, Dimitrios Tsourapas, Nilay Shah and Cleo Kontoravdi * \\ Centre for Process Systems Engineering, Department of Chemical Engineering, Imperial College London, \\ London SW7 2AZ, UK; v.thaore@imperial.ac.uk (V.T.); dimitrios.tsourapas17@imperial.ac.uk (D.T.); \\ n.shah@imperial.ac.uk (N.S.) \\ * Correspondence: cleo.kontoravdi@imperial.ac.uk
}

Received: 14 February 2020; Accepted: 7 April 2020; Published: 12 April 2020

\begin{abstract}
Cell-free protein synthesis (CFPS) is an emerging tool for the rapid production of difficult-to-express proteins as well as for identifying protein synthesis bottlenecks. In CFPS, the biotic phase is substituted by extracts of living cells devoid of any of their own genetic material. The main advantage is that these systems delineate cell growth from recombinant protein production, enabling the expression of targets that would otherwise place too big a burden on living cells. We have conducted a techno-economic analysis of a CFPS system to produce monoclonal antibodies (mAbs) using extracts of Chinese hamster ovary $(\mathrm{CHO})$ cells. We compare the performance of the CFPS system with two alternative production strategies: stable and transient gene expression in $\mathrm{CHO}$ cells. Our assessment shows that the viability of CFPS for $\mathrm{mAb}$ production requires a significant increase in the product yield and the recycling of high-cost components such as DNA. Nevertheless, CFPS shows significant promise for personalized medicine applications, providing a platform for on-demand production and simplified supply chains.
\end{abstract}

Keywords: Chinese hamster ovary cells; in vitro expression; process economics; stable gene expression; transient gene expression; cell extracts; monoclonal antibodies; recombinant proteins

\section{Introduction}

Mammalian cells have been the dominant expression system for various types of recombinant proteins including monoclonal antibodies (mAbs), fusion proteins, and other high value proteins with complex folding and post-translational modification requirements [1-3]. More than $70 \%$ of commercial $\mathrm{mAbs}$ are industrially produced in Chinese hamster ovary $(\mathrm{CHO})$ cells $[4,5]$. The large-scale production of mAbs is currently achieved by stable gene expression (SGE) of recombinant DNA, whereas transient gene expression (TGE) is also used to produce material for early-stage pre-clinical studies [6-8]. SGE involves the stable integration of the gene encoding for the recombinant protein in the DNA of the host cell, in this case $\mathrm{CHO}$ cells, by the application of a selective pressure, whereas in TGE the same gene is temporarily expressed for rapid protein production. TGE typically yields low product titres; although Backliwal et al. have reported a transient $\mathrm{mAb}$ yield $>1 \mathrm{~g} / \mathrm{L}$ in human embryonic kidney HEK-293 cells in 14 day-cultures [8], milligram quantities of recombinant mAb have mostly been reported with $\mathrm{CHO}$ cells $[9,10]$. This contrasts with $\mathrm{SGE}$, in which a 1-3 g mAb/L yield can be readily achieved [3,5], increasing to $5-10 \mathrm{~g} \mathrm{mAb} / \mathrm{L}$ in optimized fed-batch and perfusion systems [11,12].

Although $\mathrm{CHO}$ cell-based processes are successfully used for mAb production, they involve time-consuming cell line development and cloning steps for each new product [13]. Additionally, the energy trade-off between cell growth and recombinant protein production limits the product yield. Cell-free protein synthesis (CFPS) has emerged as an alternative, agnostic platform for the rapid production of small amounts of proteins that is particularly well-suited for difficult-to-express 
proteins [14,15]. Mammalian CFPS systems have been developed using Chinese hamster ovary (CHO) cell lysates, which have already been reported to produce antibodies and erythropoietin [16]. These systems offer direct access to the synthesis reaction components and environment, with ease in control and automation, while maintaining manufacturing consistency [17]. Additionally, in CFPS the generation of cell extracts is separate from the protein production steps, which simplifies the supply chain management for the manufacturing process [18]. However, the techno-economic assessment of CFPS and benchmarking against cell-based production routes are essential to ensure cost-effectiveness. The economics of cell-based production, particularly under SGE, have been widely evaluated previously [19-23].

In this work, we conduct a comparative techno-economic assessment of the manufacture of antibodies using intact $\mathrm{CHO}$ cells and $\mathrm{CHO}$ cell extracts. The CFPS process model is designed based on the experimental data reported by Thoring et al. for $\mathrm{mAb}$ synthesis using $\mathrm{CHO}$ cell lysates, essential amino acids, T7-RNA polymerase (T7-RNAP), and plasmid DNA $[15,24]$. This is compared with cell-based production at an industrial scale for stable antibody expression and at a small scale for transient antibody expression. All process models were developed and simulated in SuperPro Designer V10.0, which evaluates the overall process economics, including the total capital investment, annual operating cost, and cost of goods. We further -analyse the potential of the CFPS route by performing a rigorous sensitivity analysis considering uncertainties in various important economic factors. Finally, we consider the suitability of CFPS-based antibody expression for on-demand manufacture in personalized medicine applications and discuss opportunities for simplifying the supply chain management by improving the $\mathrm{mAb}$ manufacturing process.

\section{Materials and Methods}

SGE and TGE in CHO cells and CFPS production routes were considered to develop the process model for mAb manufacture. The simulation tool SuperPro Designer v10.0 was used to model all three production routes. Here, two production capacities were considered for the mAb manufacturing process: $200 \mathrm{~kg} / \mathrm{yr}$ for industrial scale with SGE and CFPS and $25 \mathrm{~kg} / \mathrm{yr}$ for mAb use in pre-clinical or early stage antibody drug development with TGE and CFPS.

The $\mathrm{mAb}$ production process model was divided into two main areas: upstream and downstream unit operations. The common upstream operations are inoculum preparation, fermentation, and harvest material clarification. Downstream operations mainly include Protein-A affinity chromatography, viral inactivation, ion exchange chromatography (IEX) and hydrophobic interaction chromatography (HIC), viral filtration, and polishing filtration for the final $\mathrm{mAb}$ recovery. A block diagram for each of the three production processes is presented in Figure S1.

\subsection{Upstream Processing (USP)}

\subsubsection{Stable Gene Expression}

SGE in CHO cells was considered to yield an average mAb titre of $3 \mathrm{~g} / \mathrm{L}$ in 12 days $[25,26]$. The process was designed to produce $200 \mathrm{~kg} / \mathrm{yr}$ of $\mathrm{mAb}$ as the final product. In the inoculum preparation section, seed train bioreactors were sized at $10 \%$ of the next bioreactor volume with 4 days of batch fermentation to reach a cell density of $4 \times 10^{6} \mathrm{cells} / \mathrm{mL}$. The main production fermenter was operated in a fed-batch mode at $37^{\circ} \mathrm{C}$, and cells were grown in serum-free media to reach a final density of $16 \times 10^{6}$ cells $/ \mathrm{mL}$. A fermenter volume of $5800 \mathrm{~L}$ was used for the mAb production to achieve a $3 \mathrm{~g} / \mathrm{L} \mathrm{mAb}$ titre yield in 12 days. The total cycle time was 15 days, including cleaning and sterilization. The secreted $\mathrm{mAb}$ was isolated by disk stack centrifugation and stored in a harvest tank after passing through a polishing filter. 


\subsubsection{Transient Gene Expression}

The TGE process model is based on the conservative literature value of the mAb yield of $250 \mathrm{mg} / \mathrm{L}$ in 14 days [27], although values of up to $1 \mathrm{~g} / \mathrm{L}$ have been verbally reported by leading manufacturers. The model was designed to produce $25 \mathrm{~kg}$ of $\mathrm{mAb} / \mathrm{yr}$ as the final product. In the inoculum preparation section, seed train bioreactors were sized at $10 \%$ of the next bioreactor volume with 3 days of batch fermentation to reach a cell density of $8 \times 10^{5}$ cells $/ \mathrm{mL}$. The main $\mathrm{mAb}$ production fermenter was operated in a fed-batch mode. The transfection condition was assumed as mild hypothermic with a temperature of $32{ }^{\circ} \mathrm{C}$. It was assumed that transfection is performed at a cell density of $2 \times 10^{6} \mathrm{cells} / \mathrm{mL}$ with DNA addition as $1 \mathrm{mg} / \mathrm{L}$ cell culture volume and with the transfecting agent PEI at a mass ratio of PEI:DNA as 5:1. It was further assumed that the culture commenced at $37^{\circ} \mathrm{C}$, with mild hypothermic conditions $\left(32{ }^{\circ} \mathrm{C}\right)$ introduced $24 \mathrm{~h}$ post transfection, according to Sou et al. [10].

\subsubsection{Cell-Free Protein Synthesis}

The upstream operations of CFPS consist of inoculum preparation, fermentation, cell extract preparation, and CFPS reaction for $\mathrm{mAb}$ synthesis. Like the cell-based process, the inoculum preparation was designed to reach a cell density of $4 \times 10^{6}$ cells $/ \mathrm{mL}$ in $96 \mathrm{hr}$. CHO cells were collected after 5 days of fed-batch fermentation (at a cell density of $8 \times 10^{6}$ cells $/ \mathrm{mL}$ ) by centrifugation, when they were assumed to possess a higher translational activity. Cell extract preparation: Collected cells were re-suspended in an equal amount of binding buffer and lysed by the high-pressure homogenizer at 800 bar. The lysate solution was recovered after centrifugation and then fed to the CFPS reactor. CFPS reaction: The CFPS reaction was designed based on experimental data reported by Thoring et al. for a continuous exchange $\mathrm{CHO}$ cell-free reaction (CHO-CECF) at $33^{\circ} \mathrm{C}$ with a titre of $1 \mathrm{~g} \mathrm{mAb} / \mathrm{L}$ in 2 days $[15,24]$. The CFPS reaction mixture comprised $\mathrm{CHO}$ cell-extract, CFPS medium, T7-RNA polymerase, and the DNA template. Here, CFPS medium is defined as a mixture of amino acids and energy components (Supplementary Table S1). The cell-free reaction mixture contained 50\% $(v / v)$ of $v / v$ medium and $50 \%(v / v)$ of $\mathrm{CHO}$ cell-extract solution with the addition of $40 \mathrm{nM}$ DNA and T7-RNA polymerase at $1 \mathrm{UNIT} / \mu \mathrm{L}$ of the reaction volume.

\subsection{Downstream Processing (DSP)}

DSP consisted of Protein-A chromatography, viral inactivation, two chromatographic separation steps, followed by viral filtration and then a diafiltration step for $m A b$ recovery. Protein-A chromatography: The USP-harvested cell culture fluid (HCCF) was loaded onto the Protein-A chromatography column, and the number of chromatography cycles was estimated based on an assumed mAb binding capacity of $15 \mathrm{~g} / \mathrm{L}$ [28]. Viral inactivation and polishing: Viral inactivation was performed using the detergent agent polysorbate- 80 for $1.5 \mathrm{~h}$. Subsequently, two additional chromatographic steps were included in DSP for the removal of $\mathrm{mAb}$ aggregates, residual DNA, host cell proteins (HCPs), leached protein- $\mathrm{A}$, and viral particles: ion exchange chromatography (IEX) and Hydrophobic interaction chromatography (HIC). Viral filtration: Virus removal was achieved by passing the product solution through the ultrafiltration membrane. Diafiltration: Diafiltration followed by a polishing filter was the final step considered in DSP. The purified final product $\mathrm{mAb}$ was considered to be stored at $-80^{\circ} \mathrm{C}$. It was assumed that $\mathrm{mAb}$ recovery in DSP was $75 \%$ for all three production routes at all scales $[19,25]$.

\section{Results}

The mAb manufacturing process models were designed in SuperPro Designer (v10.0) for each production route, as presented in Supplementary Figures S1-S3, which include the equipment sizes. The bulk price of all raw materials was assumed to be $10 \%$ of the advertised retail price, as specified in the Supplementary Table S1. 


\subsection{Process Economics}

\subsubsection{Large-Scale Production}

The economic analysis was performed on two different production capacities. First, we considered $\mathrm{mAb}$ production on an industrial scale, i.e., $200 \mathrm{~kg} \mathrm{mAb}$ per year by SGE in cells and CFPS. Under SGE, 20 batches of an estimated cycle time of 15 days ( $363 \mathrm{hr}$ ) each are required to achieve the production target. The batch cycle time includes a 12-day production reactor step and 3 days of cleaning and sterilization. A bioreactor with a $5800 \mathrm{~L}$ capacity is estimated to produce $13.33 \mathrm{~kg}$ of mAb per batch, designed based on the reported literature value on the $\mathrm{mAb}$ yield of $3 \mathrm{~g} / \mathrm{L}$ in 12 days achieved in the fed-batch $\mathrm{CHO}$ cell culture process [25]. The associated capital and operating costs are summarized in Table 1. The equipment cost was calculated in SuperPro Designer v10.0. With a $3 \mathrm{~g} / \mathrm{L} \mathrm{mAb}$ titre yield in USP and a 75\% mAb recovery in DSP, the total capital investment for SGE was estimated to be $\$ 47.6 \mathrm{M}$, which involves direct fixed capital $(\$ 45 \mathrm{M})$, start-up and validation costs $(\$ 2.2 \mathrm{M})$, and working capital $(\$ 0.46 \mathrm{M})$. The annual operating cost was estimated to be $\$ 17.04 \mathrm{M}$, which includes $\$ 11.02 \mathrm{M}$ USP operating costs and \$6.02 M DSP costs. A detailed analysis is provided in Supplementary Table S2. Based on the operating cost, the overall production cost for the SGE route was estimated at $\$ 85 / \mathrm{g} \mathrm{mAb}$ for a $200 \mathrm{~kg} / \mathrm{yr} \mathrm{mAb}$ production capacity facility. The annual production scale ( $\mathrm{kg} / \mathrm{year}) \mathrm{and} \mathrm{mAb}$ yield $(\mathrm{g} / \mathrm{L})$ affects the mAb cost per gram. In this paper, we further considered the variation of the annual production scale ( $\mathrm{kg} /$ year) and $\mathrm{mAb}$ yield in the sensitivity analysis below to determine the $\mathrm{mAb}$ production cost. Werner reported COG/g in the range of $\$ 260-\$ 1500 / \mathrm{g}$ for different mammalian systems producing $\mathrm{mAb}$ with a titre of 1 to $0.1 \mathrm{~g} / \mathrm{L}$, respectively, at an annual production scale of $250 \mathrm{~kg} /$ year [20,23]. Bunnak et al. provides a mAb COG (\$/g) of \$494/g and \$504/g from a fed-batch with a titre of $5 \mathrm{~g} \mathrm{mAb} / \mathrm{L}$ and perfusion (with a titre of $2 \mathrm{~g} \mathrm{mAb} / \mathrm{L}$ ) based processes, respectively, at a production scale of $28 \mathrm{~kg} /$ year [21]. Pollock et al. provides mAb COG for different process strategies of fed batches, alternating a tangential flow (ATF) in the range of $\$ 49 / \mathrm{gm}$ to $\$ 31 / \mathrm{gm}$ for a $500 \mathrm{~kg} / \mathrm{year}$ production scale with an equivalent fed-batch titre of $5 \mathrm{~g} / \mathrm{L}$ [22].

The CFPS process model was designed based on the experimental studies by Thoring et al. which reported a cell-free reaction $\mathrm{mAb}$ yield of $1.0 \mathrm{~g} / \mathrm{L}$ in 2 days [15,24]. The $\mathrm{CHO}$ cell cultivation and cell extract preparation steps were also included in the process model. In this CFPS route, the batch cycle time was estimated to be $160 \mathrm{hr}$ based on a CHO cell culture duration of $120 \mathrm{hr}$ in order to reach a cell density of $8 \times 10^{6}$ cells $/ \mathrm{mL}$, including $40 \mathrm{hr}$ of cleaning and sterilization of the bioreactor. The CFPS reaction was performed in a $7300 \mathrm{~L}$ reactor capacity, which contained $50 \%(v / v)$ cell lysates and $50 \%$ CFPS medium with $1 \mathrm{UNIT} / \mu \mathrm{L}$ of T7-RNA polymerase (T7-RNAP) and $40 \mathrm{nM}$ plasmid DNA. In the USP section, $5.82 \mathrm{~kg} \mathrm{mAb}$ was produced per batch. Assuming a $75 \% \mathrm{mAb}$ recovery in DSP, a total of $4.365 \mathrm{~kg} \mathrm{mAb}$ are produced per batch, i.e., 45 batches per year are required to achieve the production target. As given in Table 1, the capital cost for the CFPS production route was estimated to be $\$ 113.0 \mathrm{M} / \mathrm{yr}$ with a $\$ 540 \mathrm{M} / \mathrm{yr}$ operating cost. Major contributors to the high operating cost are the raw materials of T7-RNAP (65\%) and plasmid DNA (28\%). The mAb production cost was estimated to be $\$ 2700 / \mathrm{g} \mathrm{mAb}$, including raw material (95.88\%), facility dependency (2.13\%), labour dependency $(1.14 \%)$, consumables $(0.72 \%)$, and utilities costs $(0.02 \%)$. The equipment purchase cost was estimated to be $46 \%$ higher than the SGE production route due to the extensive fermentation for the extract preparation and the additional step of the cell-free reaction. 
Table 1. Process economics for mAb production for large-scale (SGE, CFPS) and small-scale manufacturing (TGE, CFPS).

\begin{tabular}{|c|c|c|c|c|c|c|}
\hline \multirow{3}{*}{ mAb Production Routes } & \multicolumn{3}{|c|}{ Large-Scale Manufacturing $200 \mathrm{~kg} \mathrm{mAb/Year}$} & \multicolumn{3}{|c|}{ Small-Scale Manufacturing $25 \mathrm{~kg} \mathrm{mAb/Year}$} \\
\hline & \multirow{2}{*}{ SGE } & \multicolumn{2}{|c|}{ CFPS } & \multirow{2}{*}{ TGE } & \multicolumn{2}{|c|}{ CFPS } \\
\hline & & without Recycled DNA & with Recycled DNA & & without Recycled DNA & with Recycled DNA \\
\hline Equipment cost & 7.17 & 10.47 & 10.47 & 7.24 & 7.42 & 7.42 \\
\hline Direct Fixed capital cost & 44.96 & 62.87 & 62.87 & 45.85 & 44.78 & 44.78 \\
\hline Working capital cost & 0.46 & 47.83 & 37.11 & 1.39 & 6.51 & 5.19 \\
\hline Start-up and validation cost & 2.25 & 3.14 & 3.14 & 2.29 & 2.24 & 2.24 \\
\hline Total Capital cost & 47.67 & 113.85 & 103.12 & 49.53 & 53.53 & 52.21 \\
\hline Raw Material cost & 0.88 & 517.73 & 362.83 & 12.64 & 65.03 & 45.91 \\
\hline Facility dependent cost & 8.22 & 11.53 & 11.53 & 8.37 & 8.21 & 8.21 \\
\hline Labour dependent cost & 3.93 & 6.15 & 6.15 & 2.27 & 6.06 & 6.06 \\
\hline Consumables & 3.82 & 3.87 & 3.87 & 0.56 & 1.17 & 1.17 \\
\hline Utilities & 0.01 & 0.10 & 0.10 & 0.03 & 0.01 & 0.01 \\
\hline Waste treatment & 0.17 & 0.59 & 0.59 & 0.10 & 0.29 & 0.29 \\
\hline Total annual operating cost (M\$) & 17.03 & 539.97 & 385.06 & 23.97 & 80.77 & 61.65 \\
\hline $\begin{array}{c}\text { Unit production cost }(\$ / \mathrm{g})= \\
\text { (total annual operating cost/annual mAb produced) }\end{array}$ & 85.17 & 2700 & 1925.32 & 958.82 & 3230.96 & 2466.00 \\
\hline
\end{tabular}




\subsubsection{Small-Scale Production}

In addition to large-scale production, we also evaluated the potential for using CFPS for the rapid provision of material for early-stage evaluation. An equivalent cell-based method is TGE, which rapidly produces material for pre-clinical studies. Commonly, TGE protocols involve a 7-14 day fermentation step (in addition to the time required to grow the cells from frozen stocks to the production reactor), whereas scaled-up CFPS could, in theory, provide the same amount of material in a timeframe of up to 2 days. Specifically, we chose to compare the two production methods for a production capacity of $25 \mathrm{~kg} / \mathrm{yr}$. The TGE process model was designed with a $250 \mathrm{mg} / \mathrm{L} \mathrm{mAb}$ yield in 14 days post transfection [9]. The production reactor has a working volume of $7420 \mathrm{~L}$, to which $7.4 \mathrm{~g}$ of DNA is added per batch ( $1 \mathrm{mg}$ of DNA per one liter of cell culture volume). A total of 16 batches are required to produce $25 \mathrm{~kg}$ of mAb per year with a batch cycle time of $460 \mathrm{hr}$. After centrifugation and cell harvest, the supernatant is transferred to the DSP section, where four cycles of Protein-A chromatography, three cycles of ion-exchange, and three cycles of hydrophobic chromatography are required for purification. For the CFPS route, the mAb synthesis yield was assumed to be $1.0 \mathrm{~g} / \mathrm{L}$ in 2 days, as before $[15,24]$. The production target can be achieved in 45 batches with a batch cycle time of $160 \mathrm{hr}$. For both production routes, the DNA cost was assumed to be $\$ 100 / \mathrm{mg}$. The cost breakdown for the total capital investment and annual operating cost is given in Table 1 . In the case of CFPS, the capital investment was calculated to be $\$ 53 \mathrm{M}$, while the annual operating cost was $\$ 81 \mathrm{M} / \mathrm{yr}$. For TGE, the capital investment was estimated to be $\$ 50 \mathrm{M} / \mathrm{yr}$ with an annual operating cost estimated at $\$ 24 \mathrm{M} / \mathrm{yr}$. The mAb production cost was estimated at $\$ 3230 / \mathrm{g}$ and $\$ 958 / \mathrm{g}$ in CFPS and TGE, respectively. DNA constitutes a significant cost component in both routes, contributing to $93 \%$ of the raw material cost in TGE and $28 \%$ in CFPS.

\subsection{Sensitivity Analysis}

A sensitivity analysis on the $\mathrm{mAb}$ production cost was performed by considering the variations of the most important process parameters that drive the economic performance of each production route. The base case values for all three routes are given in Table 2. The results are summarized in Figures 1 and 2. Under SGE, we evaluated the impact of an increase in the mAb yield from 3 to $5 \mathrm{~g} / \mathrm{L}$ : this would reduce the production cost by $10 \%$, i.e., from $\$ 85 / \mathrm{g}$ to $\$ 76 / \mathrm{g}$. In contrast, a $5 \%$ variation in raw material costs, such as less expensive serum-free cell culture media, resulted in a negligible $(0.05 \%)$ reduction in the production cost.

Table 2. The base case values for the process parameters in mAb production via SGE, CFPS, and TGE.

\begin{tabular}{cccc}
\hline \multirow{2}{*}{ Parameters } & \multicolumn{3}{c}{ Base Case Values } \\
\cline { 2 - 4 } & SGE & CFPS & TGE \\
\hline mAb yield & $3 \mathrm{~g} / \mathrm{L}$ & $1 \mathrm{~g} / \mathrm{L}$ & $250 \mathrm{mg} / \mathrm{L}$ \\
DNA concentration & - & $40 \mathrm{nM}$ & $1 \mathrm{mg} / \mathrm{L}$ \\
T7-RNAP loading & - & $1 \mathrm{UNIT} / \mu \mathrm{L}$ & - \\
T7-RNAP cost & - & $\$ 6.9 / 5000 \mathrm{UNITs}$ & - \\
DNA cost & - & $\$ 100 / \mathrm{mg}$ & $\$ 100 / \mathrm{mg}$ \\
Transfection days & - & - & 14 days \\
\hline \multicolumn{1}{c}{ Estimated mAb Production Cost, $\$ / \mathrm{g}$} \\
\hline For large-scale manufacturing, 200 kg/yr & $\$ 85 / \mathrm{g}$ & $\$ 2700 / \mathrm{g}$ & - \\
For small-scale manufacturing, 25 kg/yr & - & $\$ 3230 / \mathrm{g}$ & $\$ 958 / \mathrm{g}$ \\
\hline
\end{tabular}

Under large-scale CFPS, the raw material cost has a significant impact on process economics as it contributes to $95 \%$ of the annual operating cost. Additionally, there is a high level of uncertainty in raw material costs as prices vary significantly between different suppliers. For instance as shown in Figure $1 b$, a change to the cost of T7-RNA polymerase from the base case value of $\$ 6.9 /(5000$ UNIT) 
(New England Biolabs, NEB, UK, cited on December 2019) to \$2.0/(5000 UNIT) (Molecular Cloning Laboratories, McLab, USA, December 2019) would reduce costs by $46 \%$, i.e., from $\$ 2700 / \mathrm{g}$ to $\$ 1450 / \mathrm{g}$. Furthermore, lowering the DNA cost to $\$ 50 / \mathrm{g}$ from $\$ 100 / \mathrm{g}$, would also bring the cost down to $\$ 2322 / \mathrm{g}$. Variations in the CFPS reaction yield were also considered in the sensitivity analysis. An increase from $1.0 \mathrm{~g} / \mathrm{L}$ to $1.5 \mathrm{~g} / \mathrm{L}$ would reduce the unit cost by $32 \%$, to $\$ 1838 / \mathrm{g}$.

(a)

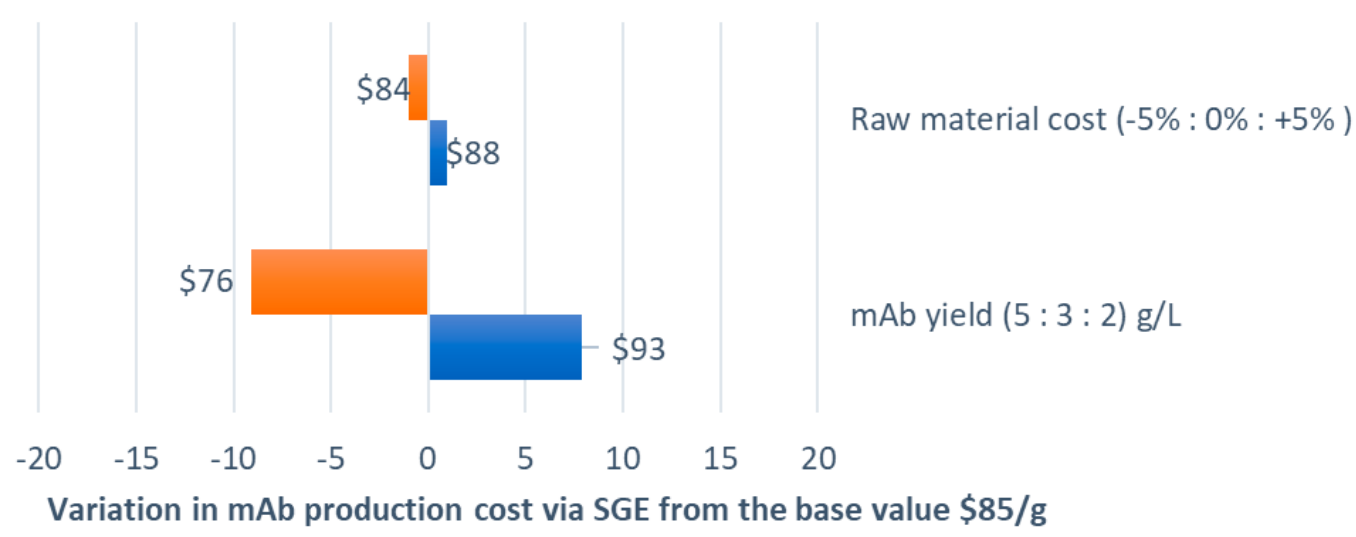

(b)

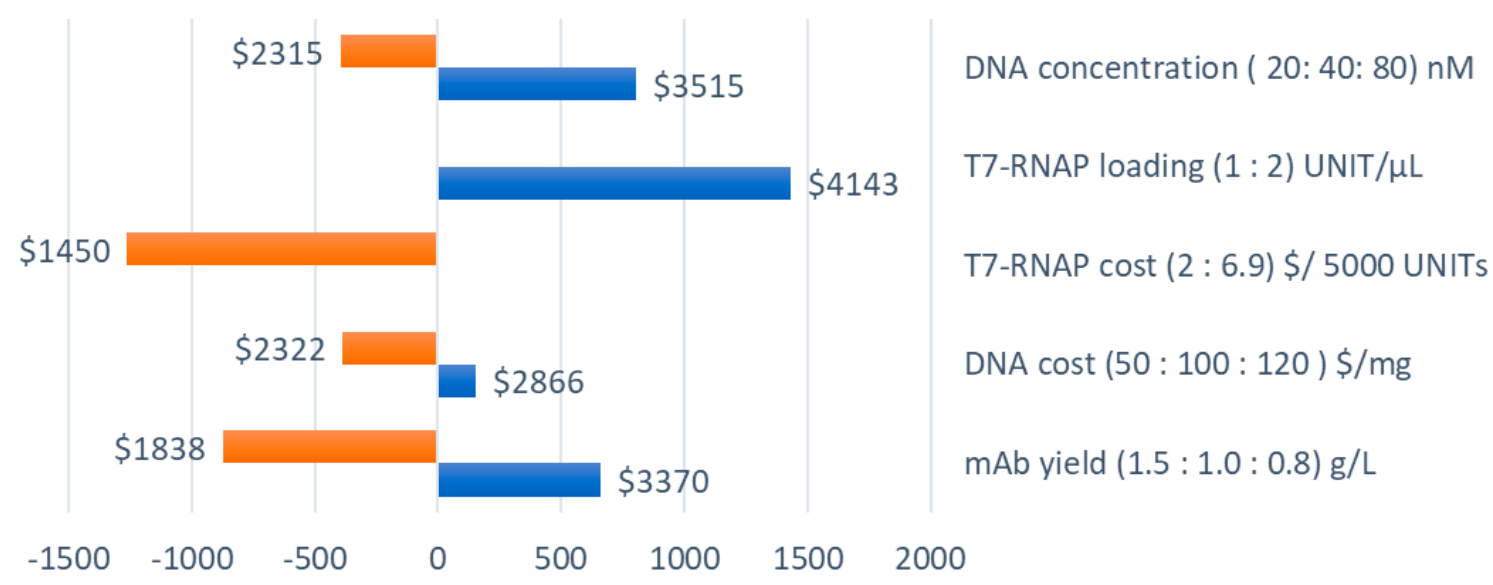

Variation in mAb production cost via CFPS from the base case value $\$ 2700 / g$

Figure 1. Sensitivity analysis of the $\mathrm{mAb}$ production cost for large-scale manufacturing, $200 \mathrm{~kg} \mathrm{mAb} /$ year via (a) SGE, base case mAb production cost $=\$ 85 / \mathrm{g}$ and (b) CFPS, base case $\mathrm{mAb}$ production cost $=\$ 2700 / \mathrm{g}$.

Figure 2a shows the sensitivity analysis results for the TGE route. The production cost was found to be dependent on the DNA cost, DNA loading per cell culture volume, mAb transfection titre yield, and cell culture duration. A reduction in the DNA cost to $\$ 50 / \mathrm{mg}$ would reduce the production cost by $25 \%$, i.e., to $\$ 721.41 / \mathrm{g}$. An increase in the $\mathrm{mAb}$ yield to $500 \mathrm{mg} / \mathrm{L}$ (base case value is $250 \mathrm{mg} / \mathrm{L}$ ) after 14 days of culture would reduce the production cost by $30 \%$. Similarly, if the base value for the yield $(250 \mathrm{mg} / \mathrm{L})$ could be achieved in 10 days instead of 14 days, the mAb production cost would be reduced by $7 \%$ to $\$ 884 / g$. However, the production cost doubles with an increase in DNA loading from 1 to $3 \mathrm{mg} / \mathrm{L}$.

Figure $2 \mathrm{~b}$ presents the sensitivity analysis results for the CFPS route at a $25 \mathrm{~kg} / \mathrm{yr}$ capacity. Herein, we evaluated the impact of the same process parameters as in the large-scale case, and the results were broadly similar in terms of the direction and magnitude of the impact on the production cost. 
(a)

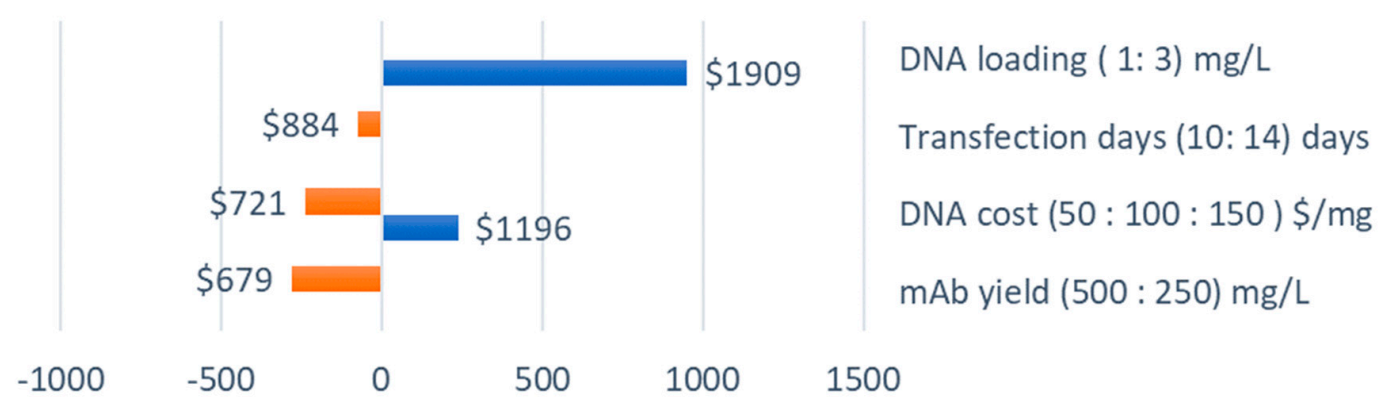

Vairation in mAb production cost vis TGE from the base value $\$ 958 / \mathrm{g}$

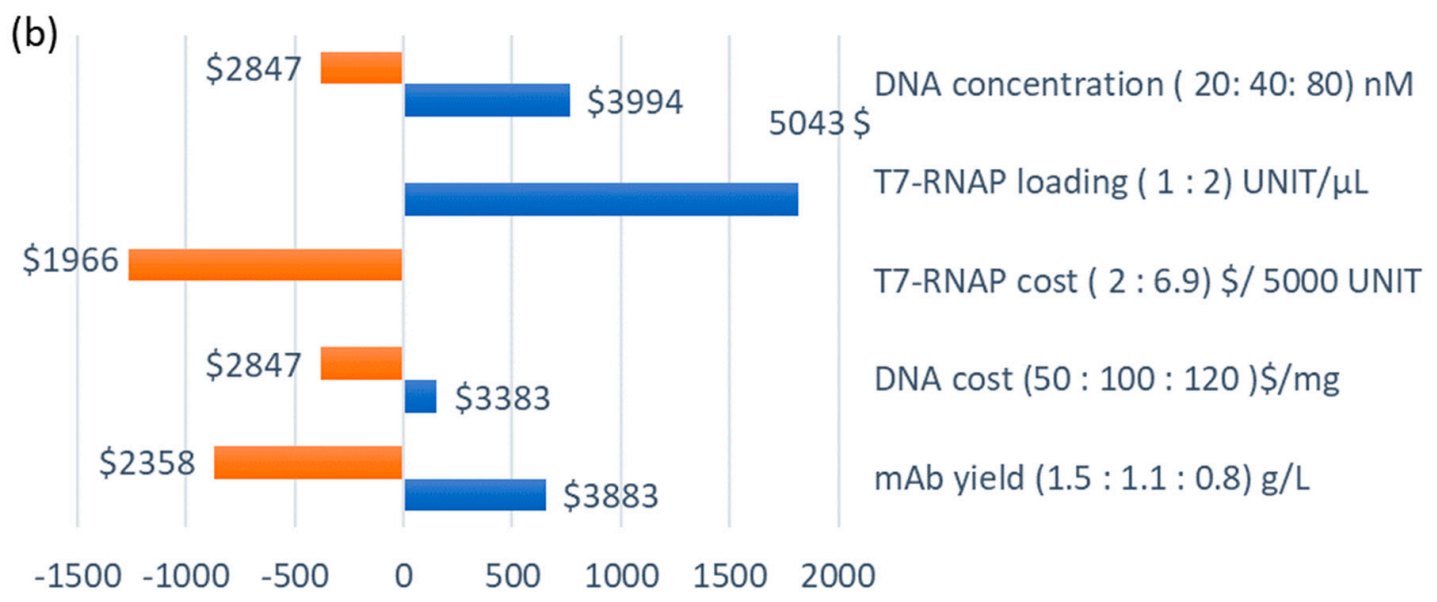

\section{Variation in mAb production cost via CFPS from the base case value $\$ 3230 / / g$}

Figure 2. Sensitivity analysis of the $\mathrm{mAb}$ production cost for small scale manufacturing, $25 \mathrm{~kg} \mathrm{mAb} / \mathrm{year}$ via (a) TGE, base case mAb production cost $=\$ 958 / \mathrm{g}$ and (b) CFPS, base case mAb production cost $=\$ 3230 / \mathrm{g}$.

Finally, Figure 3 presents the impact of the annual production scale on the mAb production cost: with an increase in the production scale, the mAb production cost decreases. However, this is dependent on the monoclonal antibodies demand for the treatment of diseases types. For large-scale manufacturing via the CFPS route, experimental validation at a demonstrated scale is important, as this could affect the process performance such as the mAb yield.

\subsection{CFPS for Personalized Medicines Manufacture}

Owing to the short reaction duration and system agility, CFPS carries a lot of promise for the on-demand production of personalized medicines. The system itself is agnostic to the protein of interest, and the DNA can be readily altered to encode for the protein of interest. CFPS can therefore serve as a production platform for a wide range of proteins on demand. Hence, we can envisage CFPS being deployed for producing proteins with patient-specific characteristics or for the treatment of orphan diseases for which large batch sizes are not required. Recently, Ogonah et al. reviewed the strengths and weaknesses of microbial and mammalian CFPS systems in terms of the sustainability of the supply chain, process scalability, and manufacturing potential for stratified medicines [18]. Since stratified medicines are targeted to a specific patient or to a group of patients, the production of a 
small-dosage amount can be achieved on-site using CFPS. Timm et al. have described a microfluidic bioreactor system where the concentration of active components was maintained with the continuous removal of inhibitors from the reaction system to achieve a high yield in the production of single-dose proteins [29]. The stratified medicine demand is dependent on the type of disease, population affected, and location where the direct supply of monoclonal antibodies or other therapeutic proteins is required. As an example, the production capacity of the Avastin monoclonal antibody could be $\sim 28 \mathrm{~kg} / \mathrm{yr}$. This was estimated based on a dose size of $15.5 \mathrm{~g}$ of Avastin mAb per person over a year for lung cancer disease. Therefore, for the treatment of lung cancer patients in the United Kingdom, $28 \mathrm{~kg}$ of $\mathrm{mAb}$ per year will be required. The Supplementary Material section S2 specifies the detailed calculation for the amount of $\mathrm{mAb}$ required over the year and the number of lung cancer patients in the United Kingdom. With the currently available data on the fixed dosing of $\mathrm{mAb}$ for the treatment of various types of cancer, the production scale could range from 1 to $28 \mathrm{~kg}-\mathrm{mAb} / \mathrm{yr}$ [21]. In this paper, we designed the process model for personalized medicine by integrating the protein synthesis step with downstream purification, as shown in Supplementary Figure S3. To develop a model for a cell-free reaction, cell-lysate, T7-RNAP, plasmid DNA, and energy components were utilized, as described in the Materials and Methods, using the same assumptions for the downstream process development as before.

(a)

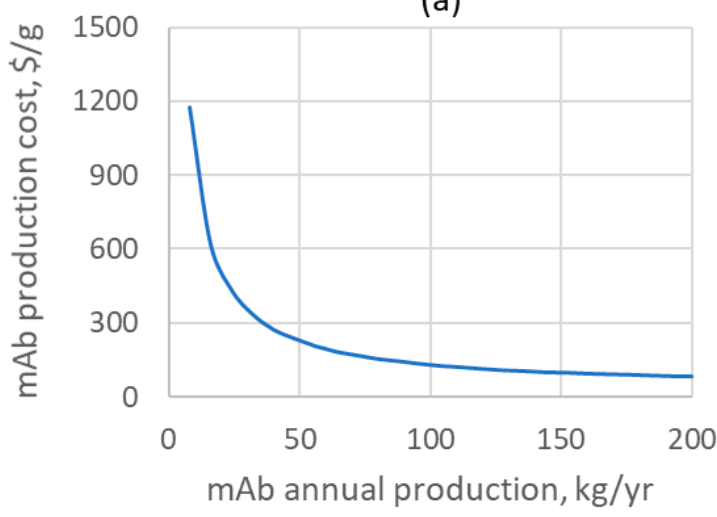

(b)

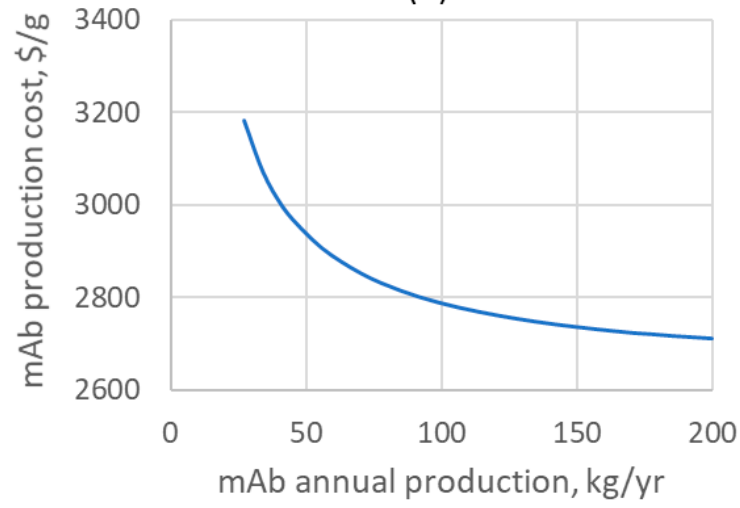

(c)

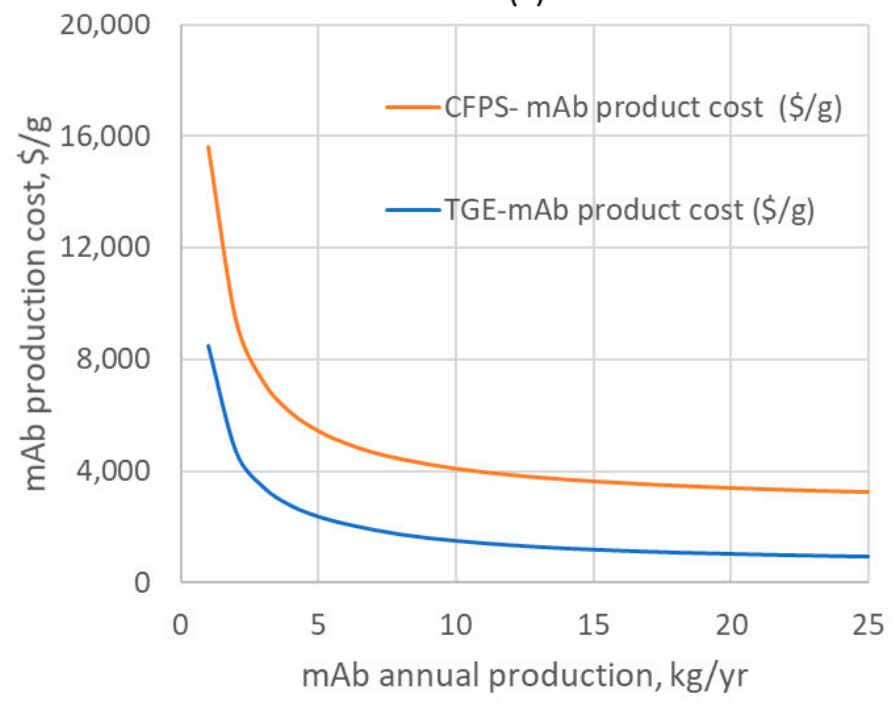

Figure 3. The $\mathrm{mAb}$ production cost versus the annual throughput capacity for (a) SGE from 8 to $200 \mathrm{~kg} / \mathrm{yr}$; (b) large-scale CFPS from 27 to $200 \mathrm{~kg} / \mathrm{yr}$; and (c) small-scale TGE and CFPS from 1 to $25 \mathrm{~kg} / \mathrm{yr}$. 
Although CFPS is typically employed for the production of small amount of proteins, Zawada et al. have demonstrated a process scale-up from $1 \mathrm{~mL}$ to $100 \mathrm{~L}$ for the consistent production of a cytokine using an Escherichia coli CFPS system [14]. Considering the scale-up consistency of CFPS, we estimated the cost of production of $\mathrm{mAb}$ for a $100 \mathrm{~L}$ reaction volume. The operating cost breakdown for the $\mathrm{mAb}$ synthesis process, including the purification step, is presented in Figure 4. Employing $100 \mathrm{~L}$ of CFPS reaction volume, $\sim 78 \mathrm{~g}$ of purified $\mathrm{mAb}$ can be produced in a batch reaction within $48 \mathrm{hr}$. The $\mathrm{mAb}$ production cost was estimated at $\$ 3585 / \mathrm{g}$. However, the production cost decreased by $22 \%$ to $\$ 2806 / g$ of $\mathrm{mAb}$ when DNA was re-used, for example using immobilization on beads [30,31]. The cost of equipment and beads for this purpose has not been included in the calculations presented herein.

With the currently available knowledge based on clinical studies on fixed dosing for lung cancer patients, $600 \mathrm{mg}$ of $\mathrm{mAb}$ are required every 2 weeks [32]. Therefore, we also considered a process with a 1 L CFPS reaction volume. Figure 4 shows the operating cost for such a small-scale reactor. In this case, the operating cost is redefined by eliminating the facility-dependent cost (FDC) related to the maintenance and depreciation of equipment used in the process flowsheet, as at this scale it would be preferable to use single-use bioreactors. The redefined operating cost per batch was estimated as $\$ 38,854$. If we consider DNA recycling, the mAb production cost was estimated to be $\$ 49 / \mathrm{mg}$. This production cost decreases to $\$ 48 / \mathrm{mg}$ when the cost of T7-RNAP is taken to be $\$ 2 / 5000$ UNITs. A $20 \%$ loss in DNA recovery results in the estimated mAb production cost varying between $\$ 42.38 / \mathrm{mg}$ and $\$ 41.12 / \mathrm{mg}$ for different T7-RNAP costs ( $\$ 6.9$ to $\$ 2 / 5000$ UNITs, respectively, as in Supplementary Table S3). A detailed analysis of the effect that the extent of DNA recovery has on COG is presented in Supplementary Figure S4.

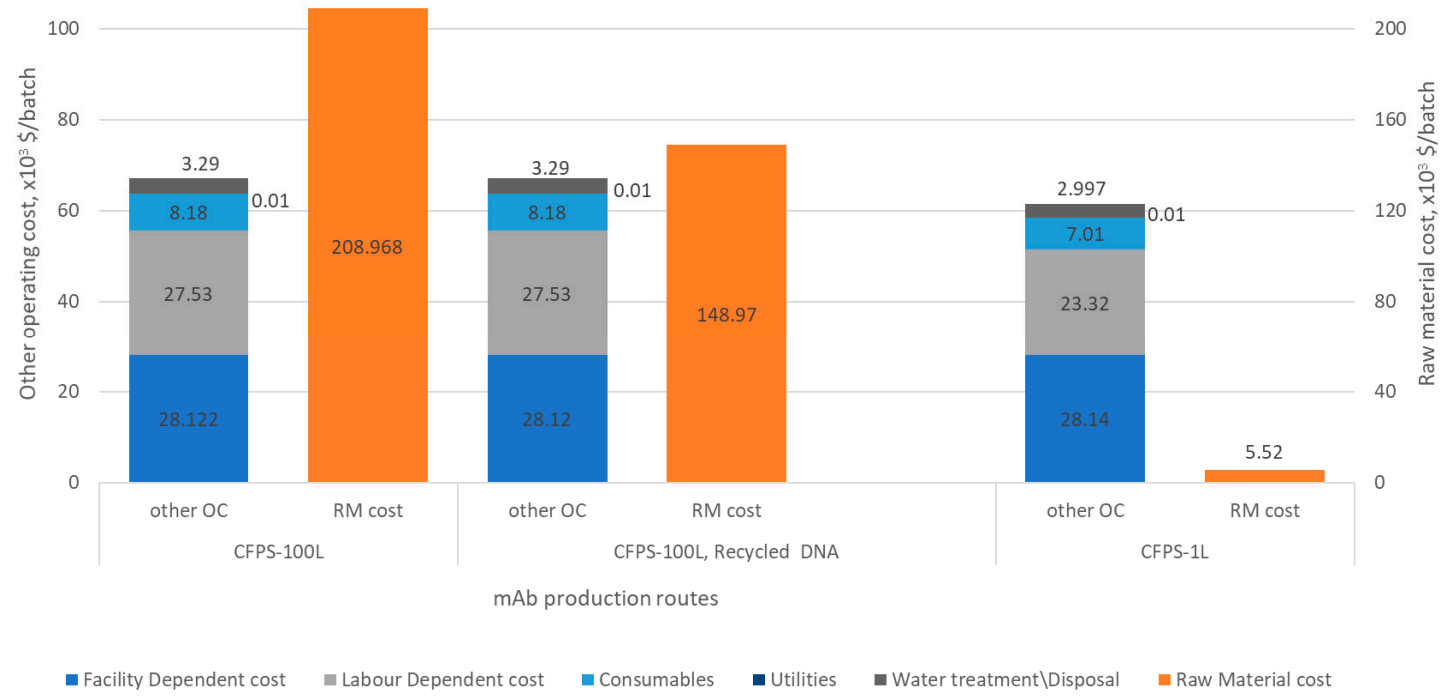

Figure 4. Total annual operating cost (in thousand \$) for $100 \mathrm{~L}$ and $1 \mathrm{~L}$ CFPS reaction volumes (other OC-Other Operating Cost = Facility-dependent, Labour-dependent, Consumables, Utilities, Water treatment/Disposal, Raw material).

Decreasing the production scale from $100 \mathrm{~L}$ to $1 \mathrm{~L}$ increases the $\mathrm{mAb}$ production cost substantially from $\$ 2.8 / \mathrm{mg}$ to $\$ 48 / \mathrm{mg}$ (Figure 4). Therefore, for the assumed mAb demand of $20 \mathrm{~g} /$ person/year, the estimated COG (i.e., raw materials cost, as shown in Figure 4 ) is in the range of $\$ 54,277 /$ person/year (100 L batch) to $\$ 127,714 /$ person/year (1 L batch). This shows the potential of CFPS for cost-effective $\mathrm{mAb}$ manufacturing and a possible alternative for the production of personalized medicine, but it is highly dependent on the production scale. The production of therapeutic proteins using CFPS could be particularly well-suited for the production of small amounts of mAb in short timeframes, as short as 2 days. Some commercial in vitro translation kits reported a high yield of protein in 7-8 hr; for instance the Thermo Scientific 1-Step Human High-Yield In Vitro Translation (IVT) Kits enables 
the expression of up to $750 \mu \mathrm{g} / \mathrm{mL}$ functional proteins with a continuous-exchange cell-free (CECF) system in 7-8 hr (Thermo Fisher, Catalog number: 88890 , Waltham, MA, U.S.A.). However, previous research has demonstrated only $100 \mathrm{mg} / \mathrm{L}$ of $\mathrm{mAb}$ production using a commercially available $\mathrm{CHO}$ extract [33]. Further development is necessary to increase the yield of CHO-based CFPS platforms to achieve the level of protein yields attainable with microbial systems, currently reported to be in the order of $1 \mathrm{~g} / \mathrm{L}$ [34].

\section{Discussion}

In this work, we explored the economics of cell-free antibody synthesis and compared these with established cell-based production routes using stable gene expression at a large scale and transient gene expression at a small scale. Commercially, Sutro biopharma utilizes the cell-free route for the production of cytokine rhGM-CSF at a $200 \mathrm{~L}$ scale [14] and antibody fragments at a $5 \mathrm{~L}$ scale using bacterial extracts [35]. In our process model, we considered larger-scale production, at $200 \mathrm{~kg} / \mathrm{yr}$. Under SGE, this target could be achieved in $6000 \mathrm{~L}$ fermenters, whereas CFPS would require two 20,000 L fermenters for cell extract preparation. The CFPS reaction itself requires a $5000 \mathrm{~L}$ reactor. Similarly, at the $25 \mathrm{~kg}$ of mAb production capacity plant, $2 \mathrm{~kg}$ of mAb can be produced per batch in a 10,000 L fermenter under TGE. In contrast, the CFPS route would require a $5000 \mathrm{~L}$ for cell extract preparation and a $\sim 1000 \mathrm{~L}$ reactor for the CFPS reaction. This inverse trend in reactor volumes can be explained by the fact that the $\mathrm{mAb}$ productivity is higher in CFPS at $0.55 \mathrm{~g} \mathrm{mAb} / \mathrm{L} /$ day in comparison to $0.25 \mathrm{~g} / \mathrm{L} /$ day in SGE and $0.017 \mathrm{~g} / \mathrm{L} /$ day in TGE.

Process economics are considerably more favorable, however, when considering the production of small amounts of product for personalized applications or for the production of orphan drugs. Limited patient numbers do not justify the construction of manufacturing facilities for the latter, which paves the way for CFPS to become the preferred production platform thanks to the limited capital expenditure that is required. The treatment costs for orphan drugs can amount to $\$ 300,000-\$ 500,000 /$ patient/year, including the recovery of Research and Development costs not accounted for herein [36]. Our estimates for COG for the low-scale CFPS platform (100 L synthesis reaction) are in line with such figures.

An advantage of the CFPS route is that the cell extract preparation steps require less monitoring than the production reactor under SGE/TGE, while the cell-free reaction step itself takes place in a fully controlled environment. Decoupling the fermentation step from the synthesis reaction also means that the components of the CFPS platform can be pre-prepared and deployed rapidly to express any product on demand, without the need to revive frozen cell stocks, which adds to time savings.

Overall, the mAb production cost was found to be higher for the CFPS route at both production scales. A cost-effective energy provision is essential when demonstrating commercial applicability. In one of the leading publications by Sutro Biopharma on immunoglobulin expression in E. coli cell-free protein synthesis [37], the authors demonstrated the use of in-house technology for the preparation of expensive reagents to reduce the reagent cost for CFPS reactions, particularly for T7-RNAP and plasmid DNA reagents. In our CFPS process model, we observed that T7-RNAP and DNA contribute to $98 \%$ of the total raw material cost. This is due to the fact that our process model takes into account the addition of fresh T7-RNAP and DNA to each batch. Recently, Levine et al. reported DNA recycling in E. coli CFPS by maintaining the magnesium levels required for DNA replication, transcription, and translation [38]. In our CFPS process model, re-using plasmid DNA could reduce operating costs by up to $29 \%$, and thus $\mathrm{mAb}$ production costs are estimated to be $\$ 2465 / \mathrm{g}$ at a smaller scale and $\$ 1933 / \mathrm{g}$ for large-scale production.

\section{Conclusions}

We performed a comprehensive techno-economic analysis on the use of a CHO cell-derived CFPS system for large- and medium-scale productions of $\mathrm{mAbs}$, as well as for the production of personalized medicines. Our results show that its cost effectiveness highly depends on scale and intended application, 
with large-scale production being less favorable to it when compared to traditional stable expression in CHO cells. In contrast, CFPS offers a higher flexibility and controllability, which is necessary for distributed manufacturing, e.g., for the on-demand provision of personalized medicines. Additionally, CFPS facilitates a considerably faster production in the order of hours/days when compared to weeks when using cell-based systems, while the associated process economics are also favorable. The detailed information presented in this work can be used for the selection of the most suitable production route based on either the processing time or the protein cost. Furthermore, the in-house preparation of expensive components would pave the way for more economical and sustainable CFPS systems.

Supplementary Materials: The following are available online at http://www.mdpi.com/2227-9717/8/4/454/s1, Figure S1: Schematic process block diagrams for large-scale mAb production (200 kg/year) by: (a) SGE and (b) CFPS; Figure S2: Schematic process block diagrams for small-scale mAb production ( $25 \mathrm{~kg} / \mathrm{year})$ by (a) TGE and (b) CFPS; Figure S3: Process flow for personalized medicine manufacturing process by CFPS; Figure S4: The effect of DNA recovery on $\mathrm{mAb} C O G, \$ /$ person/year for the assumed $\mathrm{mAb}$ demand as $20 \mathrm{~g} \mathrm{mAb/person/year.} \mathrm{(mAb}$ COG = Raw material cost); Table S1: CFPS medium components; Table S2: Process Economic data for large-scale manufacturing via SGE and CFPS production route ( $200 \mathrm{~kg} \mathrm{mAb} /$ year); Table S3: The operating cost per batch of $1 \mathrm{~L}$ CFPS reaction volume.

Author Contributions: Conceptualization, V.T., N.S. and C.K.; methodology, V.T., D.T. and C.K.; analysis, V.T. and D.T.; writing-Original draft preparation, V.T.; writing-Review and editing, V.T., D.T., N.S. and C.K. All authors have read and agreed to the published version of the manuscript.

Funding: This work was performed with financial support from the UK Engineering and Physical Sciences Research Council under grant EP/K038648/1.

Acknowledgments: The authors thank Karen Polizzi and Chiara Heide for helpful discussions.

Conflicts of Interest: The authors declare no conflict of interest.

\section{References}

1. Trill, J.J.; Shatzman, A.R.; Subinay, G. Production of monoclonal antibodies in COS and CHO cells. Curr. Opin. Biotechnol. 1995, 6, 553-560. [CrossRef]

2. Oberbek, A.; Matasci, M.; Hacker, D.L.; Wurm, F.M. Generation of stable, high-producing cho cell lines by lentiviral vector-mediated gene transfer in serum-free suspension culture. Biotechnol. Bioeng. 2010, 108, 600-610. [CrossRef] [PubMed]

3. Kunert, R.; Reinhart, D. Advances in recombinant antibody manufacturing. Appl. Microbiol. Biotechnol. 2016, 100, 3451-3461. [CrossRef] [PubMed]

4. Kim, J.Y.; Kim, Y.-G.; Lee, G.M. CHO cells in biotechnology for production of recombinant proteins: Current state and further potential. Appl. Microbiol. Biotechnol. 2011, 93, 917-930. [CrossRef]

5. Jayapal, K.; Wlaschin, K.F.; Hu, W.S.; Yap, M.G.S. Recombinant protein therapeutics from CHO Cells-20 years and counting. Chem. Eng. Prog. 2007, 103, 40-47.

6. Zhu, J. Mammalian cell protein expression for biopharmaceutical production. Biotechnol. Adv. 2012, 30, 1158-1170. [CrossRef]

7. Wurm, F.M. Production of recombinant protein therapeutics in cultivated mammalian cells. Nat. Biotechnol. 2004, 22, 1393-1398. [CrossRef]

8. Backliwal, G.; Hildinger, M.; Hasija, V.; Wurm, F.M. High-density transfection with HEK-293 cells allows doubling of transient titers and removes need for a priori DNA complex formation with PEI. Biotechnol. Bioeng. 2007, 99, 721-727. [CrossRef]

9. Rajendra, Y.; Kiseljak, D.; Baldi, L.; Hacker, D.L.; Wurm, F.M. A simple high-yielding process for transient gene expression in CHO cells. J. Biotechnol. 2011, 153, 22-26. [CrossRef]

10. Sou, S.N.; Lee, K.; Nayyar, K.; Polizzi, K.M.; Sellick, C.; Kontoravdi, C. Exploring cellular behavior under transient gene expression and its impact on $\mathrm{mAb}$ productivity and Fc-glycosylation. Biotechnol. Bioeng. 2017, 115, 512-518. [CrossRef]

11. Huang, Y.-M.; Hu, W.; Rustandi, E.; Chang, K.; Ryll, T.; Yusuf-Makagiansar, H. Maximizing productivity of $\mathrm{CHO}$ cell-based fed-batch culture using chemically defined media conditions and typical manufacturing equipment. Biotechnol. Prog. 2010, 26, 1400-1410. [CrossRef] [PubMed] 
12. Arnold, L.; Lee, K.; Rucker-Pezzini, J.; Lee, J.H. Implementation of Fully Integrated Continuous Antibody Processing: Effects on Productivity and COGm. Biotechnol. J. 2018, 14. [CrossRef] [PubMed]

13. Carlson, E.D.; Gan, R.; Hodgman, C.E.; Jewett, M.C. Cell-free protein synthesis: Applications come of age. Biotechnol. Adv. 2011, 30, 1185-1194. [CrossRef] [PubMed]

14. Zawada, J.F.; Yin, G.; Steiner, A.R.; Yang, J.; Naresh, A.; Roy, S.M.; Gold, D.S.; Heinsohn, H.G.; Murray, C.J. Microscale to manufacturing scale-up of cell-free cytokine production-a new approach for shortening protein production development timelines. Biotechnol. Bioeng. 2011, 108, 1570-1578. [CrossRef] [PubMed]

15. Thoring, L.; Dondapati, S.K.; Stech, M.; Wüstenhagen, D.A.; Kubick, S. High-yield production of "difficult-to-express" proteins in a continuous exchange cell-free system based on CHO cell lysates. Sci. Rep. 2017, 7, 11710. [CrossRef] [PubMed]

16. Brödel, A.K.; Wüstenhagen, D.A.; Kubick, S. Cell-Free Protein Synthesis Systems Derived from Cultured Mammalian Cells. Adv. Struct. Saf. Stud. 2014, 1261, 129-140.

17. Heide, C.; Ces, O.; Polizzi, K.; Kontoravdi, C. Creating cell-free protein synthesis factories. Pharm. Bioprocess. 2018, 6, 3-6.

18. Ogonah, O.; Polizzi, K.M.; Bracewell, D. Cell free protein synthesis: A viable option for stratified medicines manufacturing? Curr. Opin. Chem. Eng. 2017, 18, 77-83. [CrossRef]

19. Farid, S. Process economic drivers in industrial monoclonal antibody manufacture. Process. Scale Purif. Antib. 2009, 12, 445-466.

20. Farid, S.S. Process economics of industrial monoclonal antibody manufacture. J. Chromatogr. B 2007, 848, 8-18. [CrossRef]

21. Bunnak, P.; Allmendinger, R.; Ramasamy, S.V.; Lettieri, P.; Titchener-Hooker, N.J. Life-cycle and cost of goods assessment of fed-batch and perfusion-based manufacturing processes for mAbs. Biotechnol. Prog. 2016, 32, 1324-1335. [CrossRef] [PubMed]

22. Pollock, J.; Ho, S.V.; Farid, S.S. Fed-batch and perfusion culture processes: Economic, environmental, and operational feasibility under uncertainty. Biotechnol. Bioeng. 2012, 110, 206-219. [CrossRef] [PubMed]

23. Werner, R.G. Economic aspects of commercial manufacture of biopharmaceuticals. J. Biotechnol. 2004, 113, 171-182. [CrossRef] [PubMed]

24. Thoring, L.; Wüstenhagen, D.A.; Borowiak, M.; Stech, M.; Sonnabend, A.; Kubick, S. Cell-Free Systems Based on CHO Cell Lysates: Optimization Strategies, Synthesis of “Difficult-to-Express" Proteins and Future Perspectives. PLoS ONE 2016, 11. [CrossRef] [PubMed]

25. Kelley, B. Industrialization of $\mathrm{mAb}$ production technology: The bioprocessing industry at a crossroads. $m A b s$ 2009, 1, 443-452. [CrossRef]

26. Jiang, Z.; Droms, K.; Geng, Z.; Casnocha, S.; Xiao, Z.; Gorfien, S.; Jacobia, S.J. Fed-Batch Cell Culture Process Optimization. Bioprocess. Int. 2012, 10, 40-45.

27. Pereira, J.; Rajendra, Y.; Baldi, L.; Hacker, D.L.; Wurm, F.M. Transient gene expression with CHO cells in conditioned medium: A study using TubeSpinßbioreactors. BMC Proc. 2011, 5, P38. [CrossRef]

28. Liu, H.F.; Ma, J.; Winter, C.; Bayer, R. Recovery and purification process development for monoclonal antibody production. $m A$ ss 2010, 2, 480-499. [CrossRef]

29. Timm, A.; Shankles, P.G.; Foster, C.M.; Doktycz, M.; Retterer, S.T. Microreactors: Toward Microfluidic Reactors for Cell-Free Protein Synthesis at the Point-of-Care (Small 6/2016). Small 2016, 12, 690. [CrossRef]

30. Finkler, M.; Ott, A. Bead-based assay for spatiotemporal gene expression control in cell-free transcription-translation systems. Biotechnology 2019, 66, 29-33. [CrossRef]

31. Nord, O.; Uhlén, M.; Nygren, P.-Å. Microbead display of proteins by cell-free expression of anchored DNA. J. Biotechnol. 2003, 106, 1-13. [CrossRef] [PubMed]

32. Hendrikx, J.J.; Haanen, J.B.; Voest, E.E.; Schellens, J.H.; Huitema, A.D.; Beijnen, J.H. Fixed Dosing of Monoclonal Antibodies in Oncology. Oncology 2017, 22, 1212-1221. [CrossRef] [PubMed]

33. Martin, R.W.; Majewska, N.; Chen, C.X.; Albanetti, T.E.; Jimenez, R.B.C.; Schmelzer, A.E.; Jewett, M.C.; Roy, V. Development of a CHO-Based Cell-Free Platform for Synthesis of Active Monoclonal Antibodies. Acs Synth. Biol. 2017, 6, 1370-1379. [CrossRef] [PubMed]

34. Sutro Biopharma Inc. Xpress CFTM: A Rapid Platform for Drug Development From Antibody Discovery to Manufacturing; Sutro Biopharma Inc.: San Francisco, CA, USA, 2014. 
35. Yin, G.; Garces, E.D.; Yang, J.; Zhang, J.; Tran, C.; Steiner, A.R.; Roos, C.; Bajad, S.; Hudak, S.; Penta, K.; et al. Aglycosylated antibodies and antibody fragments produced in a scalable in vitro transcription-translation system. $m A$ Abs 2012, 4, 217-225. [CrossRef] [PubMed]

36. Jayasundara, K.; Hollis, A.; Krahn, M.D.; Mamdani, M.; Hoch, J.S.; Grootendorst, P. Estimating the clinical cost of drug development for orphan versus non-orphan drugs. Orphanet J. Rare Dis. 2019, 14, 12. [CrossRef]

37. Cai, Q.; Hanson, J.A.; Steiner, A.R.; Tran, C.; Masikat, M.R.; Chen, R.; Zawada, J.F.; Sato, A.K.; Hallam, T.J.; Yin, G. A simplified and robust protocol for immunoglobulin expression inEscherichia colicell-free protein synthesis systems. Biotechnol. Prog. 2015, 31, 823-831. [CrossRef]

38. Levine, M.; Gregorio, N.E.; Jewett, M.C.; Watts, K.R.; Oza, J.P. Escherichia coli-Based Cell-Free Protein Synthesis: Protocols for a robust, flexible, and accessible platform technology. J. Vis. Exp. 2019, e58882. [CrossRef]

(C) 2020 by the authors. Licensee MDPI, Basel, Switzerland. This article is an open access article distributed under the terms and conditions of the Creative Commons Attribution (CC BY) license (http://creativecommons.org/licenses/by/4.0/). 